\title{
A 30-Year Follow-Up of The Congenital Longitudinal Deficiency of The Tibia
}

\author{
Serap Alsancak ${ }^{l}$, Haydar Altınkaynak ${ }^{l}$ \\ ${ }^{1}$ Ankara University Vocational School of Health Services, Prosthetics and Orthotics Department, Ankara,Turkey \\ E-posta: alsancak@ankara.edu.tr
}

\begin{abstract}
Inroduction: Congenital longitudinal deficiency of the tibia is rarely uncommon occurrence. In the study was determined that both conservative treatment approaches (such as orthotics, prosthetics or orthoprosthetics) and surgical treatment, and the appropriate treatment time, appropriate treatment methods and long follow-up are required in the congenital limb deficiency.
\end{abstract}

Case Report: A male in his form baby till age into young-adult and his treatment, were considered. The purpose of this study to discuss our prosthetics and orthotics fittings and findings, and share our experience on a patient with the longitudinal deficiency of the tibia in a 30 -year period.

Conclusion: Management success of the longitudinal deficiency treatment is directly interested in team members, patient and his parent.

Keywords: Congenital longitudinal deficiency of the tibia, Orthoprosthesis

\section{Özet}

Giriş: Konjenital longitudinal tibia eksikliği nadir görülen bir durumdur. Çalışmada konjenital ekstremite yetersizliğinde konservatif tedavi yaklaşımlarının (ortotik, protez veya ortoprostetik gibi) ve cerrahi tedavinin uygun tedavi süresi, uygun tedavi yöntemleri ve uzun süre takip edilmesi gerektiği saptanmıştır.

Olgu: Bebeklikten genç-erişkin oluncaya kadarki süreçte bir erkek olguve tedavisi ele alındı. Bu çalışmanın amacı konjenital longitudinal tibia eksikliği olan bir hastada 30 yıllık takip sürecindeki protez ve ortez uygulamalarımızı ve bulgularımızı tartışmak ve deneyimimizi paylaşmaktır.

Sonuç: Konjenital longitudinal eksiklik tedavisindeki başarı doğrudan ekip üyeleri, hasta ve ailesi ile ilişkilidir.

Anahtar Kelimeler: Konjenital longitudinal tibia eksikliği, Ortoprotez 
Congenital lower limb deficiencies are present at birth and characterized as longitudinal or transverse and complete or incomplete. They can involve one or more bones, occur unilaterally or bilaterally, and are seldom associated with organ abnormalities. Tibial deficiency has been reported with deafness, ectrodactyly or polydactyly of the hands, and craniofacial defects. Sacral agenesis can cause hemipelvectomy, or hip disarticulation, and is often associated with neurogenic bowel and bladder (Werler, 1989, Krajbich et al, 2016, Alexander and Matthews, 2010, Smith, 2004).

Congenital longitudinal deficiency of the tibia is an uncommon condition involving complete or partial absence of the tibia. The etiology of tibial deficiency remains unknown (Erdem, 1996, Manner et al., 2006, Ofiaeli, 1998, Schoenecker et al., 1989, Spiegel et al., 2003, Wolfgang,1984).

Treatment of tibial deficiency is a team work. Close cooperation between the prosthetist and surgeon is required about limb shorthening and affected limb abnormalities in the knee, ankle and foot. Physiotherapist is one of the other team member to maximize the functional gains facilitated by surgical interventions and changes in prostheses, orthoses or orthoprostheses (Smith, 2004).

In this study, corrective plastic molded orthoses, orthoprostheses and prosthesis were applied in a patient. Nonsurgical and surgical treatment results were discussed together with parents effects.

\section{Material and Methods}

The patient was first seen at two months of age in 1985 with unilateral longitudinal deficiency in type I according to the system of Klamchi and Dawe (Klamchi and Dave, 1985). The left lower limb had absence of the tibia and the extensor mechanism. In addition to this tarsal bones, partial; metatarsophalangeal 1 and 2, total were absent. He had knee flexion, equinovarus foot deformities, and hip dysplasia and hemivertebra. The baby wore his first orthoses at the age two and three months. These were static progressive knee ankle foot orthosis (KAFO) with metal uprights and semi-rigid plastic KAFO with anterior knee retension, corrective foot component. At his age first year, he was pulled to standing by plastic KAFO with leg length discrepancy compensation. And then at the age of 4 years orthoprosthesis (posterior shell design) with stiff knee, corrective foot component and connected with prosthetic foot was fitted (Figure 1).
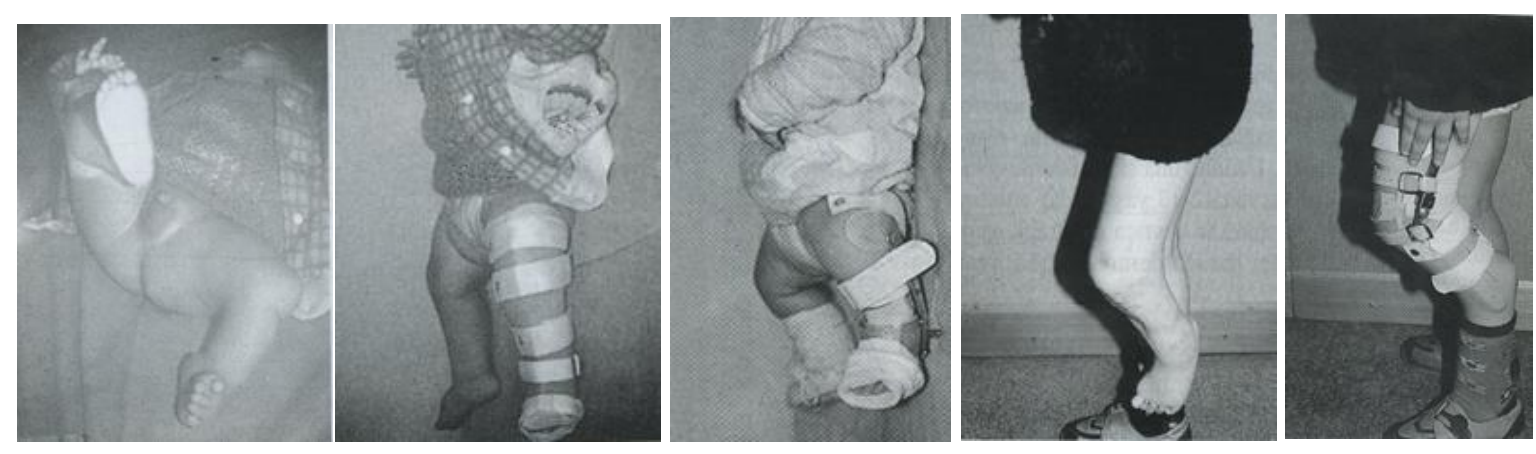

\section{Figure 1.}

He had many reconstructive surgeries between the age 4 to 6 years. Each year extention limitation of the left knee was increased and reached 45 degrees at the age of 6 years. Unesthetic orthoprosthesis; femoral corset anterior open, knee joints with drop locks and corrective knee extension band and foot component, and solid ankle foot orthosis $(\mathrm{SACH})$ foot was fitted at the age of 6 years. Fussions were 
applied for the knee and ankle at the age of 8 years. And he had worn many stiff knee orthoprostheses with anterior opening window and SACH feet the age between 8 and 30 years. Both ischial and end weight bearing were applied on the all prothetic applications. But there could not be found any solution to prevent skin irritations on the anterior surface of the lower limb and foot the last 6 years. The young patient started to want wearing a prosthesis with free knee joint. The team (surgeon, prosthetist and physiotherapist) was decided for knee disarticulation with an acceptence of the patient in 2016. After the knee disarticulation, the patient at the age of 30 years has just used a transfemoral prosthesis with IC socket, microprocessor controlled knee with dynamic response foot. Hip joint stability was provided Ischial containment (IC) socket and suspension problem was solved both suction and total elastic suspension of the prosthesis (Figure 2).
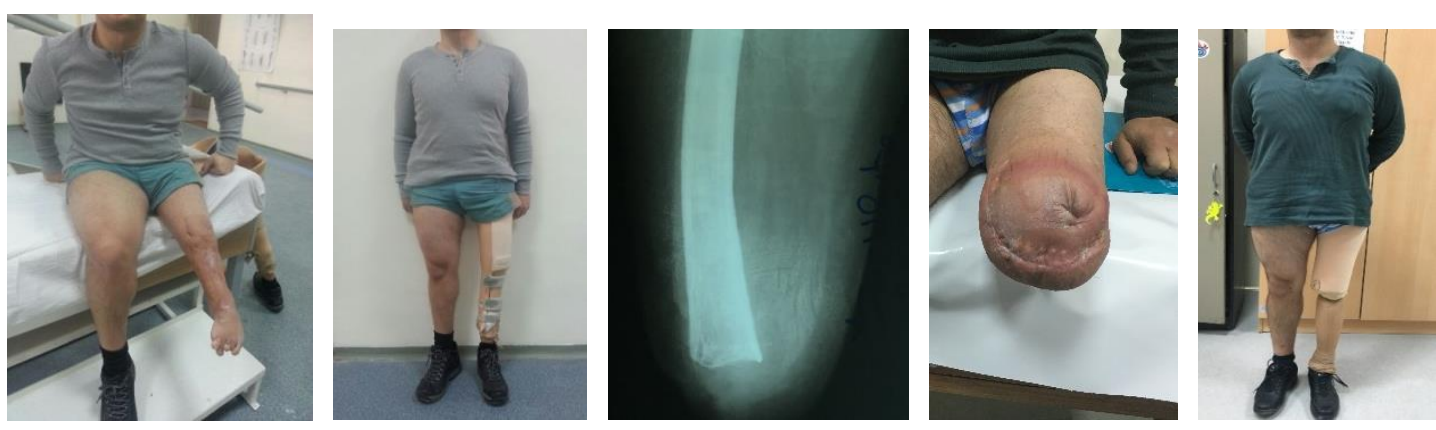

Figure 2.

\section{Conclusion}

We noted that the parents had been in a great psychological misery and stress. They could never accept the knee disarticulation in the childhood period for their son. The patient had a very difficult orthoprosthetic experience in the duration of 30 years. The result is showed that how effects close cooperation between the surgeon, parents, patient, prosthetist and orthotist and physiotherapist.

\section{References}

WERLER MM, POBER BR, NELSON K, HOLMES LB. 1989. Reporting accuracy among mothers of malformed and nonmalformed infants. Am J Epidemiol. 129:415-421.

KRAJBICH JI, PINZUR MS, POTTER LTC BK, STEVENS PM, eds. 2016 Atlas of Amputations and Limb Deficiencies: Surgical Prosthetic, and Rehabilitation Principles. $4^{\text {th }}$ ed. Rosemont, IL: American Academy of Orthopedic Surgeons.

SMITH DG, MICHAEL JW, BOWKER JH, eds. 2004. Atlas of Amputations and Limb Deficiencies: Surgical Prosthetic, and Rehabilitation Principles. $3^{\text {th }}$ ed. Rosemont, IL: American Academy of Orthopedic Surgeons.

ALEXANDER MA, MATTHEWS DJ, eds. Pediatric Rehabilitation: Principles and Practice. 4th ed. New York, NY, Demos Medical, 2010.

ERDEM H. Ekstremite Protezleri. Türk Hava Kurumu Matbaas1. 1996.

MANNER HM, RADLER C, GANGER R, GRILL F. 2006. Knee deformity in congenital longitudinal deficiencies of the lower extremity Clin Orthop Relat Res. 48:185-192. 
OFIAELI RO. 1998. Congenital longitudinal deficiency of the tibia--report of two cases, both siblings of same parentage. West Afr J Med. 17(2):121-123.

SCHOENECKER PL, CAPELLI AM, MILLAR EA, SHEEN MR, HAHER T, AIONA MD, MEYER LC. 1989. Congenital longitudinal deficiency of the tibia. J Bone Joint Surg Am. 71(2):278-287.

SPIEGEL DA, LODER RT AND CRANDALL RC. 2003. Congenital longitudinal deficiency of the tibia. International Orthopaedics (SICOT) 27(6),338-342. doi: 10.1007/s00264-003-0490-5. [PMC free article] [PubMed]

WOLFGANG GL. 1984. Complex congenital anomalies of the lower extremities: Femoral bifurcation, tibial hemimelia, and diastasis of the ankle. Case report and review of the literature. J Bone and Joint Surg (Am) 66: 453-458.

KLAMCHI A, DAVE RV. 1985. Congenital deficiency of the tibia. J Bone Joint Surg (Br) 67, 581584. 